\title{
Effects of phytoplankton bloom in a coastal ecosystem on the composition of bacterial communities
}

\author{
Beate Rink ${ }^{1}$, Susanne Seeberger ${ }^{1}$, Torben Martens $^{1}{ }^{,}$Claus-Dieter Duerselen ${ }^{2}$, \\ Meinhard Simon ${ }^{1}$, Thorsten Brinkhoff ${ }^{1, *}$
}

\author{
${ }^{1}$ Institute for Chemistry and Biology of the Marine Environment (ICBM), University of Oldenburg, PO Box 2503, \\ 26111 Oldenburg, Germany \\ ${ }^{2}$ AquaEcology, Marie-Curie-Straße 1, 26129 Oldenburg, Germany
}

\begin{abstract}
We studied the composition of free-living and particle-associated bacterial communities during the course of the phytoplankton succession in spring and early summer in the Wadden Sea, a tidal flat ecosystem in the southern North Sea. We applied the denaturing gradient gel electrophoresis (DGGE) approach based on PCR-amplified 16S rRNA gene fragments and, in addition to Bacteriaspecific primers, used primer sets targeting Alphaproteobacteria, the Roseobacter-clade and the Bacteroidetes phylum. Even though the application of the primer sets targeting Bacteria and Alphaproteobacteria detected some changes, they were most pronounced with those targeting the Roseobacter-clade and Bacteroidetes. The changes were supported by a correspondence analysis, which showed a statistically significant correlation of the DGGE banding patterns of the Roseobacter-specific PCR with the composition of the phytoplankton $(p=0.03)$. This indicates that changes in the phytoplankton composition in this habitat are not reflected by changes in the most abundant or most readily amplifiable phylotypes. The findings rather suggest that few, specialized, heterotrophic bacteria are most responsive to the organic matter supplied by distinct phytoplankton communities and that the main part of organic matter in the Wadden Sea is utilized by generalists. Sequence analyses of excised bands revealed a high diversity for the Bacteria- and Bacteroidetes-targeted approaches. The bacterial community detected by the primer set targeting Alphaproteobacteria, however, was mainly composed of bacteria affiliated to the Roseobacter-clade.
\end{abstract}

KEY WORDS: Free-living bacteria - Particle-attached bacteria Bacteroidetes - Roseobacter . Phytoplankton $\cdot$ Denaturing gradient gel electrophoresis $\cdot$ Wadden Sea

\section{INTRODUCTION}

It is well established that heterotrophic bacteria are an important component of and key players in the biogeochemical cycling of elements and the flux of energy in aquatic ecosystems (Azam et al. 1983, Cole et al. 1988). Depending on the ecosystem and on various environmental and biotic factors, the composition of the bacterial communities involved may exhibit distinct differences and variations in time and space (Fandino et al. 2001, Trousselier et al. 2002, Selje \& Simon 2003). The most important factor selecting for specific bacterial groups is supply by specific monomeric and polymeric components of the dissolved organic carbon (DOC) pool and of inorganic nutrients such as phosphate, ammonium or nitrate. It has been shown that Alphaproteobacteria prefer monomers such as amino acids and N-acetyl-glucosamine, whereas Cytophaga/Flavobacteria (now Sphingobacteria/Flavobacteria) of the Bacteroidetes phylum prefer polymers such as chitin and protein, and Gammaproteobacteria amino acids and proteins (Cottrell \& Kirchman 2000). Various mesocosm studies have shown that distinct DOC components via direct supply or the experimental induction of phytoplankton blooms select for specific bacterial subcommunities or popula- 
tions (LeBaron et al. 1999, Riemann et al. 2000, Schäfer et al. 2001, Pinhassi et al. 2004, Abell \& Bowman 2005). The specific organic matter profile of various algae appears also to be an important selection factor for distinct bacterial communities and populations evolving in the phycosphere of algae (Grossart 1999, Schäfer et al. 2002, Grossart et al. 2005). In fact, Alphaproteobacteria, in particular the Roseobacter-clade, and the Sphingobacteria/Flavobacteria group appear to be most responsive to inputs of phytoplankton-born DOC and organic sulfur compounds (Riemann et al. 2000, Fandino et al. 2001, Schäfer et al. 2001, Moran et al. 2003, Pinhassi et al. 2004, Grossart et al. 2005).

It is also well established that the community composition of particle-associated (PA) bacteria differs from that of free-living (FL) bacteria. Several studies have shown that Sphingobacteria and Flavobacteria preferentially colonize particles whereas Alpha- and Gammaproteobacteria mainly dwell in free-living marine bacterial communities (Fandino et al. 2001, Simon et al. 2002, Grossart et al. 2005). Our knowledge on the development and succession of specific subcommunities and populations within PA bacterial communities during phytoplankton blooms, however, is still fragmentary.

Experimental studies are important for elucidating single factors affecting the composition of bacterial communities. As the aim of such studies is to better understand how the composition of bacterial communities is controlled at ambient, but much more complex, conditions, it is important to complement these studies with appropriate field observations. Such studies have been carried out in various ecosystems and have shown that the composition of bacterial communities undergoes temporal changes during phytoplankton blooms (Fandino et al. 2001, Yager et al. 2001, Larsen et al. 2004). These changes often reflect the changing environmental conditions and DOM supply and also indicate which bacteria are mainly involved in the biogeochemical cycling of elements and flux of energy. Denaturing gradient gel electrophoresis (DGGE) of PCR-amplified 16S rRNA gene fragments using Bacteria-specific primers (Muyzer et al. 1993) has been proven to be a powerful tool to assess the composition and temporal changes of bacterial communities. Using Bacteria-specific primers for this approach appears to be selective against the Bacteroidetes phylum (Cottrell \& Kirchman 2000, Selje et al. 2005, but see Castle \& Kirchman 2004). Therefore, and to obtain a more detailed insight into the composition of bacterial communities and their major players, it is desirable to apply primers targeting specifically important groups such as Sphingobacteria/ Flavobacteria of the Bacteroidetes phylum and Alphaproteobacteria.
The aim of the present study was to investigate the composition of free-living and particle-associated bacterial communities during the course of the phytoplankton succession in spring and early summer in the Wadden Sea, a tidal flat ecosystem of the southern North Sea. Based on previous studies, we hypothesized that the expected bacterial response to the phytoplankton succession would be reflected most pronouncedly by Alphaproteobacteria and the Sphingobacteria/Flavobacteria group. Therefore, we applied the DGGE approach and, in addition to Bacteria specific primers, primers targeting Alphaproteobacteria, the Roseobacter-clade, and the Sphingobacteria/Flavobacteria group.

\section{MATERIALS AND METHODS}

Sample collection and processing. Surface water samples were collected weekly by bucket from shipboard at high tide from 12 April to 29 June 2000 in the Backbarrier tidal flat ecosystem of the German Wadden Sea near Spiekeroog Island ( $\left.53^{\circ} 44.4^{\prime} \mathrm{N}, 7^{\circ} 41^{\prime} \mathrm{E}\right)$. This is a mesotidal ecosystem characterized by high loads of suspended particulate matter (SPM) (for further details see Stevens et al. 2005a and Lunau et al. 2006). For analysis of SPM and the particulate carbon fractions 0.5 to 11 of seawater was filtered onto precombusted $\left(2 \mathrm{~h}\right.$ at $\left.550^{\circ} \mathrm{C}\right)$ and pre-weighed glass fiber filters (GF/F, Whatman) and stored at $-20^{\circ} \mathrm{C}$ in the dark until further processing. For DGGE analysis, $250 \mathrm{ml}$ of seawater were pre-filtered onto $5.0 \mu \mathrm{m}$ polycarbonate-filters (Nuclepore) to obtain the fraction of particle-associated bacteria and subsequently onto $0.2 \mu \mathrm{m}$ polycarbonate-filters to obtain that of FL bacteria. Filters were stored at $-20^{\circ} \mathrm{C}$ in the dark until further processing. For enumeration of bacterial and phytoplankton cells $100 \mathrm{ml}$ of water sample were fixed with formaldehyde (final concentration $2 \% \mathrm{vol} / \mathrm{vol}$ ) or Lugol and stored at $4^{\circ} \mathrm{C}$. Hydrographic data (temperature, salinity, $\mathrm{pH}$, and oxygen) were measured by probes (LF 196, pH192, OXI 196, WTW).

SPM dry weight: particulate carbon fractions. Filters were dried for $1 \mathrm{~h}$ at $110^{\circ} \mathrm{C}$ and weighed on a micro-balance (Sartorius). Total particulate carbon (TC) and particulate inorganic carbon (PIC) were determined after high-temperature combustion and titration of the $\mathrm{CO}_{2}$ produced against $\mathrm{Ba}\left(\mathrm{ClO}_{4}\right)_{2}$. Particulate organic carbon (POC) was calculated as the difference between TC and PIC (for further details see Stevens et al. 2005a).

Bacterial and algae cell counts. Abundance of FL and PA bacteria was enumerated after DAPI (4'-6diamidino-2-phenylindole) staining by epifluorescence microscopy at $1000 \times$ magnification according to 
Crump et al. (1998). To distinguish PA and FL bacteria, seawater was fractionated by filtration onto $5.0 \mu \mathrm{m}$ and subsequently onto $0.2 \mu \mathrm{m}$ polycarbonate-filters. To reduce the background fluorescence from inorganic matter, filters were counter-stained with an acridine orange solution $(0.1 \%)$. Lugol-fixed phytoplankton samples were enumerated by inverted microscopy. Phytoplankton was identified to species level when possible. For estimating phytoplankton biomass, cell numbers were multiplied by cell carbon. The latter was estimated from measured cell sizes of individual cells converted to carbon according to empirical carbon/cell volume conversion factors from the Biologische Anstalt Helgoland (J. Berg unpubl. data).

Nucleic acid extraction. The isolation of genomic DNA was performed by phenol-chloroform extraction after bead-beating as described by Selje \& Simon (2003), with slight modifications. Precipitation was done overnight at $-20^{\circ} \mathrm{C}$ using isopropanol. The DNA was resuspended in molecular grade water (Eppendorf) and stored at $-20^{\circ} \mathrm{C}$ until further processing.

Primer sets. PCR amplification of $16 \mathrm{~S}$ rRNA gene fragments was performed with primer pairs specific for Bacteria (GC-341F and 907RM), and targeting the Bacteroidetes phylum (classes Sphingobacteria, Flavobacteria, Bacteroides) (GC-CF319f and 907RM), Alphaproteobacteria (GC-341F and ALF968r), and the Roseobacter-clade within Alphaproteobacteria (GCROSEO536Rf and GRb735r). Primer sequences and references are given in Table 1. 'GC' indicates that a GC clamp was added to the primer (Muyzer et al. 1993). For the primer GC-ROSEO536Rf the following GC clamp was used: 5'-CGCCCGCCGCGCCCCGCGCCCGTCCCGCCGCCCCCGCCCG-3'. For the sequences of the other GC clamps used in this study see sources cited in Table 1. Specificity of the primers used for Bacteroidetes has been described earlier by Jaspers et al. (2001) and Kirchman (2002). The oligonucleotide probe ALF968r (Neef 1997), used as reverse primer for Alphaproteobacteria, was tested theoretically using the BLAST function of the NCBI server (www.ncbi.nlm.nih.gov). Search results for this primer sequence revealed up to $10 \%$ matches with other phylogenetic groups with $100 \%$ sequence similarity for the first 100 matches. The primer set used for the Roseobacter-clade was tested theoretically with the whole database of the ARB software package (Ludwig et al. 2004) and recently published sequences present in GenBank (www.ncbi.nlm.nih.gov) of cultivated and uncultivated organisms affiliated with the Roseobacter-clade. In total, 183 sequences affiliated with this group were considered. Specificity was also tested in PCR assays using several described species as positive and negative controls (Table 2), and 25 isolates affiliated with the Roseobacter-clade selected from our culture collection.

PCR amplification of 16S rRNA gene fragments. PCR amplifications were performed with an Eppendorf Mastercycler (Eppendorf) as follows: $1 \mu$ of template was added to $49 \mu \mathrm{l}$ of PCR mixture containing $1 \mathrm{U}$ of Sigma RedTaq ${ }^{\mathrm{TM}}$ polymerase and $5 \mu \mathrm{l} 10 \times \operatorname{RedTaq}^{\mathrm{TM}}$ PCR buffer (Sigma), bovine serum albumin (10 mg $\mathrm{ml}^{-1}$ ), $250 \mu \mathrm{M}$ of each deoxynucleotide triphosphate, $2.1 \mu \mathrm{M} \mathrm{MgCl}_{2}$, and $20 \mathrm{pmol}$ of each primer. The PCR protocol for the Bacteria-specific primer set was performed as described by Brinkhoff \& Muyzer (1997). Amplification of the 16S rRNA gene fragments of Alphaproteobacteria was performed under the same conditions with an annealing temperature of $65^{\circ} \mathrm{C}$ for 10 cycles and subsequently $55^{\circ} \mathrm{C}$ for 20 cycles. Roseobacter-specific PCR conditions were 5 cycles at $65^{\circ} \mathrm{C}$ and 25 cycles with an annealing temperature of $63^{\circ} \mathrm{C}$. For highest specificity, a maximum of 30 cycles is recommendable at this step. PCR with the primer set targeting Bacteroidetes was performed as described by Jaspers et al. (2001). For the sample of FL bacteria of 31 May, PCR products had to be reamplified before use for DGGE due to weak amplification of the original sample. Four $\mathrm{ml}$ of the amplification products were analyzed by electrophoresis in $2 \%(\mathrm{w} / \mathrm{v})$ agarose gels and stained with ethidium bromide $\left(1 \mathrm{mg} \mathrm{ml}^{-1}\right.$ ) (Sambrook et al. 1989). For subsequent sequencing analysis PCR products were purified by using the Qiaquick PCR purification kit (Qiagen I).

DGGE analysis of PCR products. DGGE was performed with the D-Code system (Bio-Rad Laborato-

Table 1. Primers used in this study. GC: GC clamp added to primer; *: modified

\begin{tabular}{|c|c|c|c|c|}
\hline Primer & Sequence $\left(5^{\prime}-3^{\prime}\right)$ & $\begin{array}{l}\text { E. coli } 16 \mathrm{~S} \\
\text { rRNA position }\end{array}$ & Target group & Source \\
\hline GC-341F & CCTACGGGAGGCAGCAG & $341-358$ & Bacteria & Muyzer et al. (1993) \\
\hline 907RM & CCGTCAATTCMTTTGAGTTT & $907-924$ & Universal & Muyzer et al. (1998) \\
\hline GC-CF319f & GTACTGAGACACGGACCA & $319-336$ & Bacteroidetes & Manz et al. (1996) \\
\hline ALF968r & GGTAAGGTTCTGCGCGTT & $968-985$ & Alphaproteobacteria & Neef (1997) \\
\hline GC-ROSEO536Rf & CGGAGGGGGTTAGCGTTG & $536-553$ & Roseobacter-clade & Brinkmeyer et al. (2000) \\
\hline GRb735r* & GTCAGTATCGAGCCAGT(G/A)AG & $735-754$ & Rhodobacter group & Giuliano et al. (1999) \\
\hline
\end{tabular}


Table 2. Phylogenetic affiliation of strains and species used for specificity test of Roseobacter primer set. Strains are from culture collection of our laboratory or the DSMZ (German Collection of Cell Cultures and Microorganisms). DSMZ strain numbers in parentheses. Organisms of the Roseobacter-clade comprised positive control, the other organisms negative controls. na: not available

\begin{tabular}{|c|c|c|}
\hline Class & Strain or species (DSMZ No.) & Acc. No. \\
\hline $\begin{array}{l}\text { Alphaproteobacteria } \\
\text { (Roseobacter-clade) }\end{array}$ & $\begin{array}{l}\text { TL } \\
\text { T11 } \\
\text { TY } \\
\text { D1 } \\
\text { D4 } \\
\text { HP12 } \\
\text { HP14w } \\
\text { HP29w } \\
\text { HP30 } \\
\text { HP32 } \\
\text { HP37 } \\
\text { HP44w } \\
\text { HP47 } \\
\text { HP50 } \\
\text { ROS2 } \\
\text { ROS4 } \\
\text { ROS7 } \\
\text { ROS8 } \\
\text { AP-27 } \\
\text { H43-35 } \\
\text { GWS-BW-H55M } \\
\text { GWS-BW-H22M } \\
\text { GWS-BW-H66M } \\
\text { GWS-BW-H71M } \\
\text { Phaeobacter inhibens (16374) } \\
\text { Phaeobacter gallaeciensis (17395) } \\
\text { Roseobacter denitrificans (7001) } \\
\text { Marinovum algicola (10251) } \\
\text { Ruegeria gelatinovorans (5887) } \\
\text { Roseovarius tolerans (11457) } \\
\text { Leisingera methylohalidivorans (14336) } \\
\text { Sulfitobacter pontiacus (10014) }\end{array}$ & $\begin{array}{l}\text { AY177716 } \\
\text { AY177714 } \\
\text { AY841772 } \\
\text { AY841770 } \\
\text { AY841771 } \\
\text { AY239003 } \\
\text { AY841773 } \\
\text { AY239008 } \\
\text { AY239009 } \\
\text { AY841774 } \\
\text { AY239010 } \\
\text { AY841775 } \\
\text { AY841776 } \\
\text { AY841778 } \\
\text { AY841779 } \\
\text { AY841780 } \\
\text { AY841781 } \\
\text { AY841782 } \\
\text { AY145564 } \\
\text { AY841784 } \\
\text { AY515418 } \\
\text { AY515407 } \\
\text { AY515422 } \\
\text { AY515423 } \\
\text { AY177712 } \\
\text { Y13244 } \\
\text { M59063 } \\
\text { X78315 } \\
\text { D88523 } \\
\text { Y11551 } \\
\text { AY005463 } \\
\text { Y13155 }\end{array}$ \\
\hline Alphaproteobacteria & Paracoccus aminophilus (8538) & D32239 \\
\hline Betaproteobacteria & $\begin{array}{l}\text { Curvibacter delicatus (11558) } \\
\text { Burkholderia pyrrocinia (10685) } \\
\text { Sphaerotilus natans (6575) }\end{array}$ & $\begin{array}{l}\text { AF078756 } \\
\text { AB021369 } \\
\text { L33980 }\end{array}$ \\
\hline Gammaproteobacteria & $\begin{array}{l}\text { Pseudomonas putida (548) } \\
\text { Pseudeoalteromonas atlantica (6839) } \\
\text { Fundibacter jadensis (12178) }\end{array}$ & $\begin{array}{l}\text { AF094741 } \\
\text { X82134 } \\
\text { AJ001150 }\end{array}$ \\
\hline Deltaproteobacteria & $\begin{array}{l}\text { Desulfococcus multivorans (2059) } \\
\text { Desulfobulbus mediterraneus (13871) } \\
\text { Pelobacter venetianus (2394) }\end{array}$ & $\begin{array}{l}\text { AF418173 } \\
\text { AF354663 } \\
\text { U41562 }\end{array}$ \\
\hline Flavobacteria & Muricauda ruestringensis (13258) & AF218782 \\
\hline Bacilli & $\begin{array}{l}\text { Bacillus marinus }(1297) \\
\text { Bacillus subtilis }(10) \\
\text { Lactobacillus plantarum (20205) }\end{array}$ & $\begin{array}{l}\text { AJ237708 } \\
\text { AJ276351 } \\
\text { na }\end{array}$ \\
\hline Actinobacteria & $\begin{array}{l}\text { Streptomyces violaceoruber (40701) } \\
\text { Streptomyces glaucescens (40155) } \\
\text { Streptomyces antibioticus }(40715) \\
\text { Arthrobacter nicotinovorans }(420)\end{array}$ & $\begin{array}{l}\text { na } \\
\text { D44092 } \\
\text { na } \\
\text { X80743 }\end{array}$ \\
\hline
\end{tabular}

ries). For each lane, 400 to $600 \mathrm{ng}$ of the PCR amplification products were applied. For gene fragments of Bacteria and Alphaproteobacteria, the protocol described by Brinkhoff \& Muyzer (1997) was used. For 16S rRNA gene fragments obtained with the primer pair GC-CF319f and 907 RM, the gradient was modified to 15 to $85 \%$ denaturant. DGGE analysis of
Roseobacter 16S rRNA gene fragments was performed with 20 to $70 \%$ denaturant and 9\% (wt/vol) polyacrylamide content. After electrophoresis, the gels were stained with SYBR Gold (Molecular Probes) and photographed using a BioDoc Analyze Transilluminator (Biometra). Bands were excised with a scalpel sterilized with ethanol and transferred to sterile 
Eppendorf tubes. We added $50 \mu \mathrm{l}$ of water (molecular grade, Eppendorf) and the samples were stored at $-20^{\circ} \mathrm{C}$.

Band reamplification and cloning. DGGE bands were reamplified with the same primer sets and screened by DGGE to check if the amplicons matched the positions of the corresponding DGGE bands and sequenced (see below); 24 of the 44 DGGE bands excised (GWS-e1-FL to GWS-e13-PA, GWS-c3-FL, GWS-c16-PA， GWS-c9-PA， GWS-c10PA, GWS-c18-PA and GWS-a10-PA to GWS-a13-PA, GWS-a4-FL, GWS-a8-FL) did not yield reliable sequences and, therefore, were cloned using the pGEM $^{\circledR}-\mathrm{T}$ Vector System II (Promega) following the instruction manual. Clones with inserts were picked, resuspended in molecular grade water (Eppendorf) and screened again by DGGE to check if the insert position matched the position of the corresponding DGGE band. Adequate clones were amplified and subsequently sequenced using the primers pUC/ M13f and pUC/M13r (Messing 1983) with an annealing temperature of $48^{\circ} \mathrm{C}$.

Sequencing and phylogenetic analysis. PCR products were sequenced using the DYEnamic Direct cycle sequencing kit (Amersham Life Science) and a Model 4200 automated DNA sequencer (LI-COR). Sequencing primers labeled with IRDye ${ }^{\mathrm{TM}} 800$ were $341 \mathrm{~F}$ and 907RM for sequencing of reamplified DGGE bands, or M13 primers (Messing 1983) for cloned bands. For all sequences, at least $400 \mathrm{bp}$ were determined. Phylogenetic affiliation of the sequences was determined using the BLAST function of the NCBI server (www.ncbi.nlm.nih.gov/BLAST/). Phylogenetic trees were constructed using the ARB software package (Ludwig et al. 2004, see: www.arb-home.de). The backbone tree was calculated with the maximum likelihood method using sequences with a minimum length of $1300 \mathrm{bp}$, including type strains of the selected phylogenetic groups. For tree calculation, positions were excluded at which less than $50 \%$ of all sequences showed the same residues to avoid uncertain alignments. Sequences with less than $1300 \mathrm{bp}$ were added to the backbone tree with the maximum parsimony method using the same filter. As an outgroup, 16S rRNA gene sequences of 7 type strains belonging to Cyanobacteria were used.

The sequences obtained in this study are available from GenBank under Accession Nos. DQ080919 to DQ080962.

Statistics. Cluster analyses of DGGE banding patterns were performed using Gel Compar II, Version 2.5 (Applied maths, Kortrijk). Calculations were curve-based, using Pearson correlation and UPGMA. A correspondence analysis of the DGGE banding patterns and the phytoplankton composition was per- formed using ADE-4 (Thioulouse et al. 1997). To analyze the bacterial community structure, we exported the positions of the DGGE bands from the cluster analysis as raw data and generated a matrix based on the presence/absence of bands at a specific height. (For further details of this analysis see Johnson et al. 2006). For phytoplankton, we used relative species abundance. A modified correspondence analysis (COA) including both the bacterial and phytoplankton communities was performed row-weighted on a biplot scale. Therefore, the presence/absence and patterns of the matrices of a given sample were compared. After calculation of the COA a Coinertia analysis was performed to connect the data. A permutation test based on the Monte Carlo method was calculated using the Coinertia test ( - fixed $D$; number of random matching: 1000).

\section{RESULTS}

\section{Environmental conditions and SPM properties}

From the start of the study period in mid-April until 10 May 2000 the water temperature continuously increased from 8 to $17^{\circ} \mathrm{C}$ (Fig. 1A). Thereafter it fluctuated between 17 and $13^{\circ} \mathrm{C}$. Salinity ranged between 29 and $32 \%$ (Fig. 1A) and SPM dry weight from 80 to $120 \mathrm{mg} \mathrm{l}^{-1}$ in April and May, but increased to $160 \mathrm{mg} \mathrm{l}^{-1}$ on 14 June (data not shown). Lowest and highest concentrations of total particulate carbon and POC occurred on 3 May and 26 April and ranged from 1.5 to $5.9 \mathrm{mg} \mathrm{l}^{-1}$ and from 0.8 to $4.7 \mathrm{mg} \mathrm{l}^{-1}$, respectively (Fig. 1B). They steadily increased from 3 to 17 May and from 24 May to 14 June.

\section{Phytoplankton and bacterial dynamics}

The phytoplankton consisted exclusively of diatoms (Fig. 1C) and a few dinoflagellates, mainly Ceratium spp. From 12 April to 3 May diatom cell numbers strongly decreased from $6.5 \times 10^{3}$ to $1.2 \times 10^{3} \mathrm{l}^{-1}$ but thereafter continuously increased until 24 May. After the decline of this bloom in late May only low numbers were detected. Whereas the initial bloom on 12 April exhibited high diversity and evenness, the bloom in May became more and more dominated by Guinardia delicatula, constituting $70 \%$ of algal cell numbers and biomass on 24 May (Fig. 1C). One week later, when diatom cell numbers had declined to $\sim 30 \%$ of those in the previous week, the abundance of G. delicatula had strongly decreased while Pseudonitzschia pungens constituted $50 \%$ of the cell numbers. At the onset of the study phytoplankton consti- 

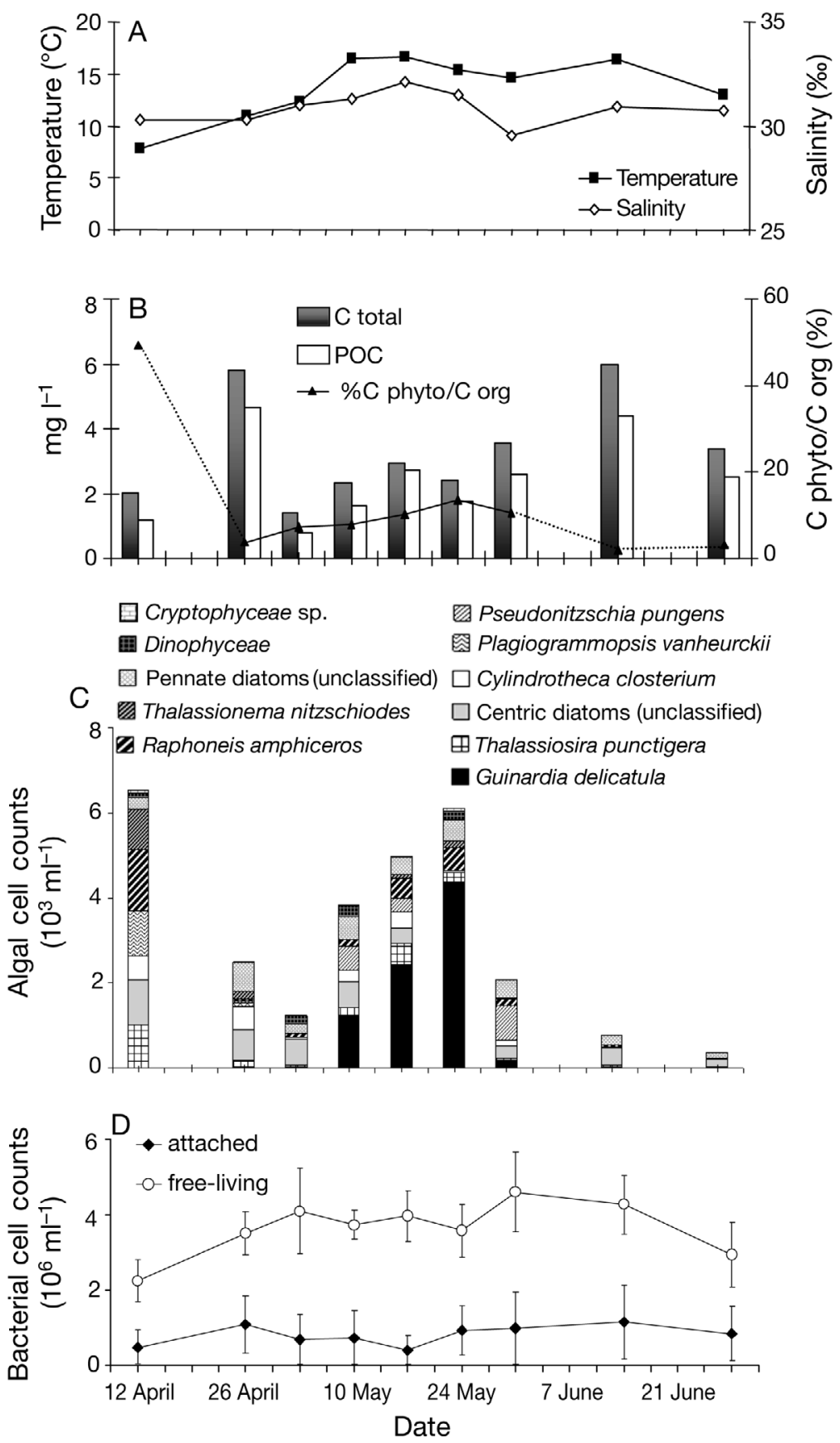

Fig. 1. (A) Temperature and salinity, (B) total particulate carbon (C total), particulate organic carbon (POC) and phytoplankton carbon (C phyto) as \% of POC, (C) phytoplankton cell counts and species composition, and (D) abundance of particle-attached and free-living bacteria in the German Wadden Sea from 12 April to 29 June 2000

tuted $50 \%$ of POC, but on 26 April only $4 \%$. Thereafter, during the G. delicatula bloom, phytoplankton carbon continuously increased to $13 \%$ on 24 May (Fig. 1B).

Cell numbers of FL bacteria increased from 12 April until 3 May from $2.4 \times 10^{6}$ to $4.0 \times 10^{6} \mathrm{ml}^{-1}$, fluctuated around the latter value until 14 June, and declined thereafter (Fig. 1D). Cell numbers of PA bacteria were lower and ranged from $0.5 \times 10^{6}$ to $1.1 \times 10^{6} \mathrm{ml}^{-1}$ without pronounced temporal changes. They accounted for 11 to $22 \%$ of total bacterial numbers.

\section{Specificity of Roseobacter primer set}

Comparison of 16S rRNA gene fragments present in our ARB database revealed that the forward primer GCROSEO536Rf matched 131 of a total of 183 target sequences affiliated to the Roseobacter-clade; 43 Roseobacter sequences had no or incomplete information at the target site of the primer, and 8 sequences of uncultured Roseobacter-affiliated organisms showed up to 3 mismatches with the primer sequence; Sulfitobacter pontiacus (Acc. No. Y13155) had 1 mismatch at Position 17 of the primer sequence; reverse primer GRb735r targeted 133 sequences after insertion of a wobble (G/A) at Escherichia coli Position 752; 44 Roseobacter sequences had no or incomplete information at the target site of the 16S rRNA gene; 6 sequences of target bacteria had up to 3 mismatches: Roseobacter sp. J8W (AF026462, 2 mismatches), Roseobacter sp. J2W (AF026462, 3 mismatches), Roseobacter sp. KT1117 (AF173971, 1 mismatch), Adriatic 72 (AF030780, 1 mismatch, 2 non-defined bases), Sulfitobacter pontiacus (Y13155, 1 mismatch) and GWS-BW-H66M (AY515422, 1 mismatch). The non-target sequences of Rhodovulum iodosum and clone SAR102 (Acc. No. L35460) had no mismatch with the primer sequence. Considering all respective sequences in the ARB data base, the use of both primer pairs resulted in at least 1 mismatch with all other phylogenetic groups.

PCR results showed that the specificity and sensitivity of the Roseobacter primer set was very high. With 1 step down from 65 to $63^{\circ} \mathrm{C}$ and $1 \mathrm{U}$ of $T a q$ polymerase, $0.2 \mathrm{ng}$ genomic DNA $\mu^{-1}$ of Phaeobacter gallaeciensis was detectable. DNA of the non-target organism Paracoccus aminophilus (1 mismatch to the target sequence) was

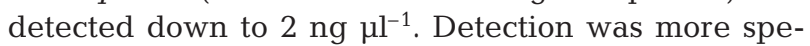
cific but less sensitive under the same conditions with 
$0.5 \mathrm{U}$ of polymerase, detecting 0.1 to $1 \mathrm{ng} \mathrm{DNA} \mu \mathrm{l}^{-1}$ of $P$. gallaeciensis and $20 \mathrm{ng}$ DNA $\mu^{-1}$ of $P$. aminophilus. To determine a possible sequence preference of the primer set, a DNA mixture of both organisms with equal DNA amounts was amplified and the PCR products were analyzed using DGGE. By this approach only amplicons of P. gallaeciensis were detected (data not shown). This suggests that the amplification of non-target organisms is suppressed under the chosen PCR and DGGE conditions.

Due to the small fragment size of the Roseobacterspecific PCR amplicons (<200 nucleotides, Table 1), bands were not excised for sequencing.

\section{DGGE banding patterns}

The DGGE analyses with the various primer sets showed distinctly different banding patterns of the FL compared to the PA bacterial communities (Fig. 2). The Bacteria-specific primer set yielded 12 to 15 bands per lane in the PA bacterial fraction and 12 to 18 bands in the FL bacterial fraction (Fig. 2A). Changes in the banding patterns occurred mainly during the Guinardia-bloom in May, showing a slight increase of band numbers in the FL fraction on 17 May and the appearance of a strong band in the PA fraction (GWS-e11$\mathrm{PA})$. The cluster analysis yielded distinct clusters for

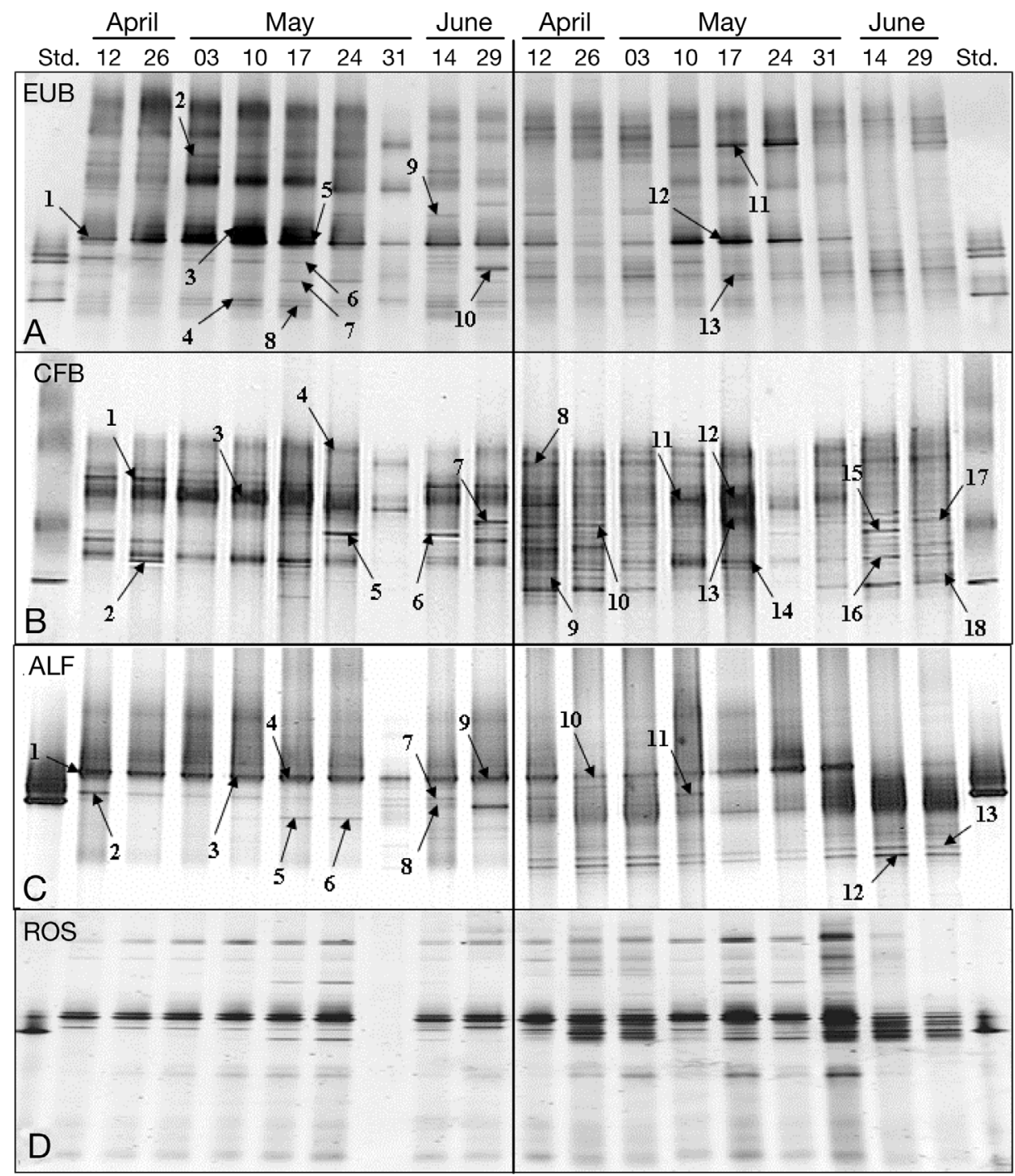

FL

PA

Fig. 2. DGGE fingerprints of free-living (FL) and particle-attached (PA) bacterial communities of the German Wadden Sea from 12 April to 29 June 2000 using primer sets for 16S rRNA genes of (A) Bacteria (EUB), (B) Bacteroidetes (CFB), (C) Alphaproteobacteria (ALF), (D) Roseobacter-clade (ROS). Numbered arrows mark excised and sequenced bands. Because of small fragment size of Roseobacter amplicons, DGGE bands were not excised for sequencing. Std. = standard 

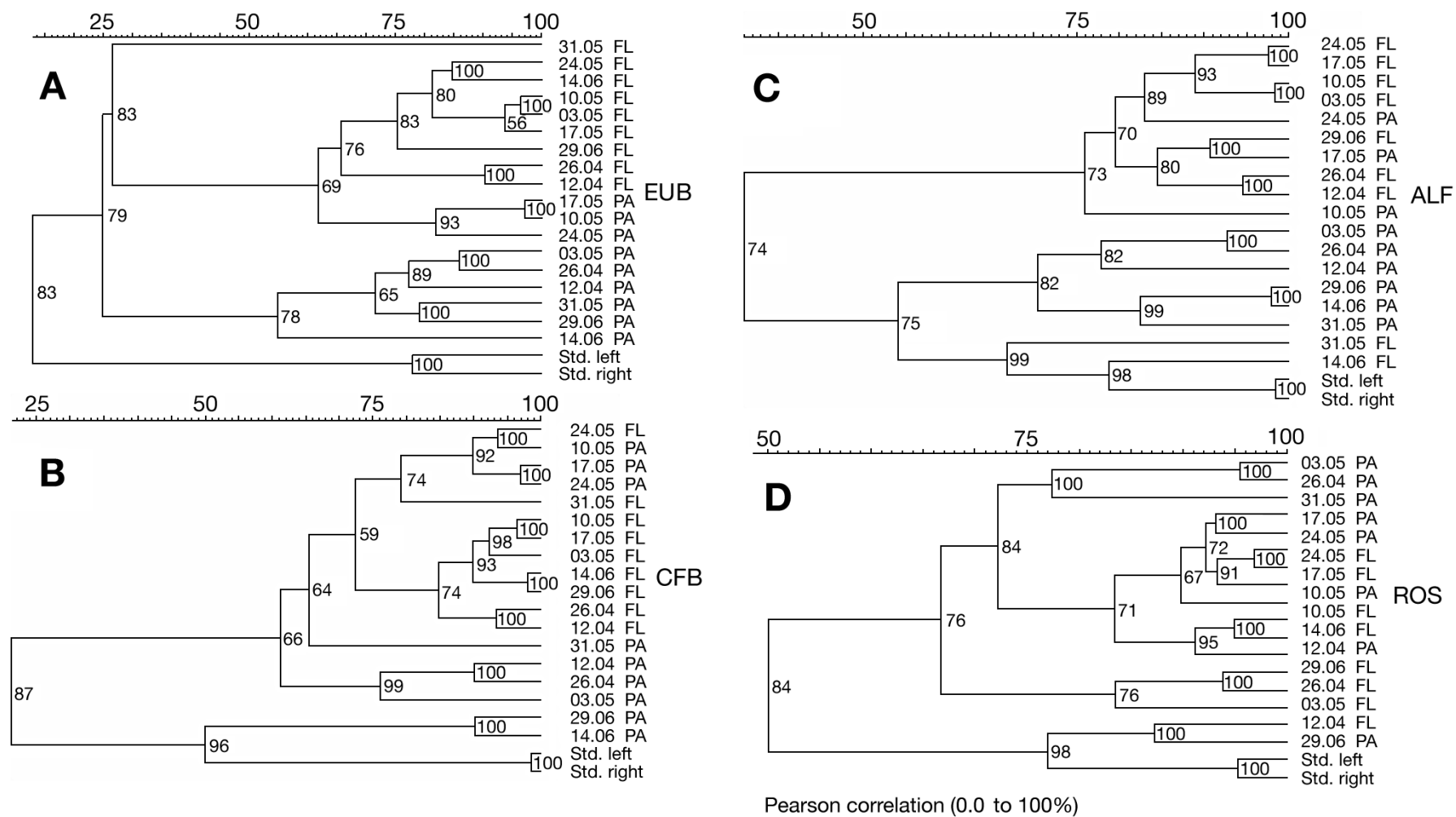

Fig. 3. Cluster analyses of DGGE banding patterns of particle-attached (PA) and free-living (FL) bacteria using UPGMA. (A) Bacteria (EUB), (B) Bacteroidetes (CFB), (C) Alphaproteobacteria (ALF) and (D) Roseobacter-clade (ROS). Similarity matrix calculated using Pearson correlation

the FL and PA bacterial communities (Fig. 3A). Only during the G. delicatula bloom between 10 and 24 May did the PA bacteria cluster closer with the FL bacterial community and separately from the PA bacteria of the other periods. Correspondence analysis did not yield a significant correlation with the phytoplankton composition. The sample of FL bacteria of 31 May, reamplified from a former PCR product, showed reduced band numbers compared to the other samples. Hence, the fingerprint of this sample appeared as an outgroup in the cluster analysis and is not regarded in the further discussion.

The Bacteroidetes-specific banding patterns revealed 7 to 12 and 9 to 18 amplicons per lane in the FL and PA bacterial fractions, respectively (Fig. 2B). Low numbers of 7 to 9 bands occurred in the FL bacterial fraction before and after the Guinardia delicatula bloom and higher numbers of 10 to 12 bands during the bloom. In contrast, the number of bands in the PA bacterial community was high before and after, and decreased during the bloom. The cluster analysis showed a distinct cluster of the FL bacterial community, excluding the dates towards the end of the G. delicatula bloom, when banding patterns clustered together with those of the PA bacterial community during the bloom (Fig. 3B). Furthermore, the latter fraction exhibited different patterns before and after the bloom. A correspondence analysis revealed a non-significant correlation of the banding patterns with the composition of the phytoplankton $(p=0.067)$.

DGGE banding patterns of the amplicons of the Alphaproteobacteria-targeted PCR showed 7 to 8 and 8 to 13 bands per lane in the FL and PA bacterial communities, respectively (Fig. 2C). Most of the bands were permanently present but a few bands in both fractions occurred in the course of the bloom (GWSa11-PA, GWS-a6-FL, and GWS-a5-FL). The cluster analysis showed generally rather complex patterns and that PA bacteria during the G. delicatula bloom clustered together with FL bacteria (Fig. 3C). The correspondence analysis did not yield a significant correlation of the banding patterns with the phytoplankton composition.

The Roseobacter-specific DGGE banding patterns showed 5 to 8 bands per lane in the FL bacterial fraction and 8 to 18 bands in the PA bacterial fraction (Fig. 2D). Quite a few bands were permanently present in both fractions, but additional bands occurred during the decline of the bloom in April and the Guinardia delicata bloom in May, mainly in the PA bacterial fraction. The cluster analysis yielded complex patterns with several subclusters both of FL and 
PA bacterial fractions. A distinct subcluster comprised the banding patterns of both fractions during the $G$. delicata bloom (Fig. 3D). The correspondence analysis showed a significant correlation of the banding patterns with the composition of the phytoplankton $(\mathrm{p}=$ 0.03).

\section{Phylogenetic affiliation}

The sequence analysis of excised bands revealed a high diversity of the obtained phylotypes for the $16 \mathrm{~S}$ rRNA gene fragments of the Bacteria- and Bacteroidetes-specific approaches (sequences obtained with Bacteria-specific primers were designated GWS-e and sequences obtained with Bacteroidetes-specific primers GWS-ci Fig. 4). The bacterial community detected by the Alphaproteobacteria-targeted primer set (Sequences GWS-a) was mainly composed of bacteria belonging to the Roseobacter-clade. Most phylotypes of this group, detected by the Bacteria- and Alphaproteobacteria-targeted primer sets, clustered within the recently described WAC I cluster (Stevens et al. 2005b) or RCA cluster (Selje et al. 2004). The primer set used for Alphaproteobacteria turned out to be not specific, as sequencing results revealed that 2 sequences affiliated to Deltaproteobacteria (GWSa12-PA, GWS-a13-PA) and 1 to Bacteroidetes (GWSa8-FL). In contrast, although the Primer GC-CF319f used for amplification of 16S rRNA gene sequences of bacteria belonging to Bacteroidetes is known to be nonspecific (Kirchman et al. 2003), all our phylotypes of the sequenced bands fell into this phylum.

During the Guinardia delicatula bloom, DGGEderived phylotypes belonging to the WAC I cluster dominated the FL bacterial fraction. DGGE Band GWS-e7-FL was present during the bloom. This phylotype was closely related to GWS-a6-FL and GWS-a5FL (sequence differences $<0.8 \%$, Fig. $4 \mathrm{~A}$ ) which were also present only during the G. delicatula bloom. While these organisms seem to be highly responsive to the phytoplankton composition, other members of the WAC I cluster were present during the whole investigation period, e.g. GWS-e6-FL (Fig. 4A). This phylotype is closely related to DGGE Band GWS-FL-3, which was persistently detected throughout the year in the Wadden Sea, indicating that this organism is well adapted to highly variable biotic and environmental conditions in this habitat (Stevens et al. 2005a). In the PA bacterial fraction, chloroplast DNA (GWS-e11-PA) represented the most significant change within the community detected by the Bacteria-specific primer set. Sequencing of other conspicuous bands was not possible, as the diffuse bands in the upper part of the gel could not be reamplified.
One of the Bacteroidetes-specific phylotypes appeared during 24 May to 14 June at the end of the Guinardia delicatula bloom in both the FL and PA bacterial fractions (GWS-c6-FL, GWS-c5-FL and GWSc15-PA). This phylotype is closely related to GWS-e9FL in the FL bacterial fraction (Fig. 4B). BLAST results revealed that the closest related sequence of these bands is DGGE Band GWS-AG-8, which was detected on aggregates in June 2000 in the same area (Stevens et al. 2005a). Other phylotypes affiliated to the Bacteroidetes were present during the whole investigation period. DGGE band GWS-c8-PA was detected in the PA bacterial fraction from April to June and is closely related to Strain T15 (AY177723, 99\% similarity, $502 / 505 \mathrm{bp})$, isolated from the same habitat in October 1999 (Brinkhoff et al. 2004). The phylotype was also detected in a seasonal and interannual study in this habitat from 2000 to 2002 using GC-CF319f and 907RM for DGGE analysis (S. Seeberger unpubl. data).

\section{DISCUSSION}

Our results indicate that the composition of the bacterial communities in the Wadden Sea underwent changes during the phytoplankton succession in spring and early summer. These changes, detected as the disappearance of DGGE bands and the appearance of new ones, were most pronounced during the Guinardia delicatula bloom and its decline in May, and occurred in the FL as well as in the PA bacterial communities. The cluster analysis of the DGGE banding patterns of all target groups indicated that the FL and PA bacterial communities were distinctly different, but became more similar during the $G$. delicatula bloom, suggesting that the environmental and substrate conditions in the bulk water and on particles during this bloom did not differ as much as before and after the bloom. Even though the application of Bacteria- and Alphaproteobacteria-targeted primer sets in the DGGE approach detected some of the changes, they were detected most clearly with the Roseobacter- and Bacteroidetes-specific primer sets and supported by a correspondence analysis. Whereas the number of bands of the FL bacterial fraction within the Bacteroidetes increased during the G. delicatula bloom, it decreased in the PA bacterial fraction. Within the Roseobacter-clade, the number of bands of the PA bacterial fraction increased during the decline of both blooms, in late April and late May. Hence our results show that the bacterial communities respond to the changing phytoplankton community and organic matter field at a fairly specific phylogenetic level and call for the application of class- and subclass-specific primer sets in the DGGE approach. 
A

Fig. 4. Phylogenetic trees of (A) Proteobacteria and (B) Bacteroidetes phylum calculated by maximum-likelihood based on 16S rRNA gene fragments. Sequences obtained in this study in bold

strain AP-27 (AY145564)

strain TL (AY177716)

strain AS-21 (AJ391182)

clone KT0202a (AF305498)

GWS-a7-FL (DQ080936)

clone Flo-55 (AY684338)

GWS-a2-FL (DQ080933)

clone DC5-80-8 (AY145594)

GWS-a11-PA (DQ080940)

clone GWS-FL-3 (AY274229)

GWS-e6-FL (DQ080924)

clone Flo-38 (AY684337)

- GWS-e7-FL (DQ080925)

clone Flo-39 (AY684334)

GWS-a6-FL (DQ080935)

clone Flo-08 (AY684335)

- clone Flo-56 (AY684336)

4 GWS-a5-FL (DQ080938)

- clone PLY-P3-48 (AY354823)

clone NAC11-7 (AF245635)

- clone ZD0207 (AJ400341)

GWS-e3-FL (DQ080921)

clone DC5-80-3 (AY145589)

clone DC11-80-2 (AY145625)

clone NAC11-3 (AF245632)

- GWS-e12-PA (DQ080930)

- GWS-e5-FL (DQ08092)

clone Flo-04 (AY684340)

GWS-a1-FL (DQ080932)

- clone GWS-AG-2 (AY274236)

[ GWS-a4-FL (DQ080943)

clone GWS-FL-2 (AY274228)

GWS-a3-FL (DQ080934)

GWS-e1-FL (DQ080919)

clone Flo-09 (AY684344)

- clone Flo-15 (AY684341)

clone Flo-54 (AY684342)

clone Flo-37 (AY684343)

GWS-a9-FL (DQ080937)

WAC I

Ocladecabacter arcticus (U73725)

Ruegeria gelatinovorans (D88523)

Oceanicola granulosus (AY424896)

Ketogulonicigenium vulgarum (AF136849)

Jannaschia helgolandensis (AJ438157)

clone KTc0993 (AF235129)

GWS-e10-FL (DQ080928)

clone WM11-36 (AF497864)

clone AY-57 (AJ298357)

Roseovarius tolerans (Y11551)

- Leisingera methylohalidivorans (AY(

gallaeciensis (Y13244)

Ruegeria algicola (X78315)

- Sulfitobacter brevis (Y16425)

Sulfitobacter brevis (Y16425)

Sulfitobacter mediterraneus (Y17387)

Staleya guttiformis (Y16427)

Oceanibulbus indolifex (AJ550939)

GWS-a10-PA (DQ080939)

clone Flo-13 (AY684347)

- Roseobacter litoralis (X78312)

Roseobacter denitrificans (M59063) Antarctobacter heliothermus (Y11552) Sagittula stellata (U58356)

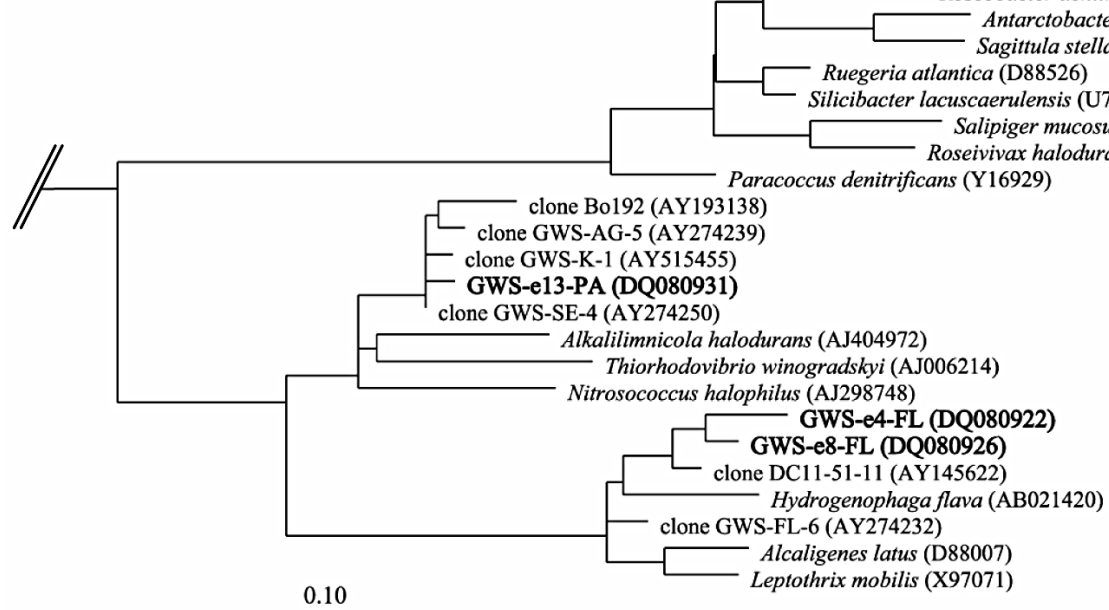

Gamma

RCA 
B

Fig. 4. (continued)

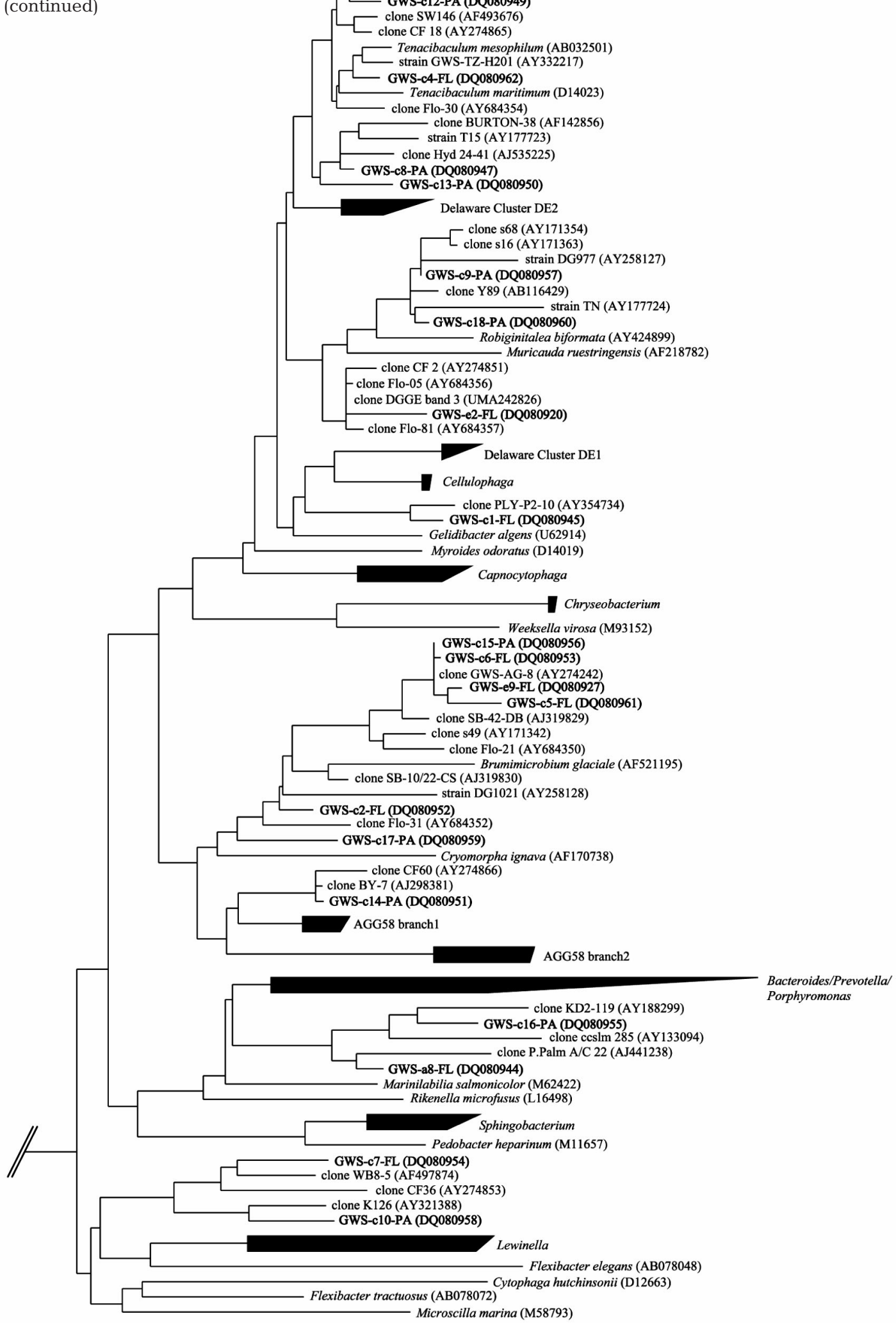


Our investigation complements mesocosm experiments which obtained similar findings (LeBaron et al. 1999, Riemann et al. 2000, Schäfer et al. 2001, Pinhassi et al. 2004, Abell \& Bowman 2005) and demonstrate that changes in FL as well as PA bacterial communities during the development of phytoplankton blooms occur and can be detected under ambient conditions in a natural ecosystem also. Our results, however, go beyond the above-mentioned experimental studies by showing in a more detailed way the different responses of bacteria affiliated to the Roseobacter-clade and Bacteroidetes.

To achieve these results we applied sets of published primers for all bacterial target groups and modified specific probes for the Roseobacter-clade from earlier studies to optimize its specificity (Table 1). In addition, we developed a PCR protocol to achieve highest specificity for this primer set. As expected from the BLAST search, the results revealed that the Alphaproteobacteria-targeted primer set was not specific. We detected 2 sequences affiliated to Deltaproteobacteria and 1 to the Bacteroidetes phylum, indicating that sequencing of bands is essential when applying this primer set. However, the great majority of the bands sequenced affiliated to Alphaproteobacteria and exclusively to the Roseobacter-clade, underscoring the significance of applying a primer set specific for this clade. Unspecific PCR-amplification of an Alphaproteobacteria targeted primer has also been reported by Riemann \& Winding (2001). In contrast to the Alphaproteobacteria targeted primer set, that targeting Bacteroidetes was specific, as all sequenced bands affiliated with the respective target group.

Although various prominent bands were visible using the group-specific primer set, only 2 Bacteroidetes affiliated phylotypes were detected with the Bacteria-specific primer set. Only 1 of these 2 phylotypes was also detected with the group-specific primer set (GWS-e9-FL, Fig. 4B) suggesting that the Bacteriaspecific primer set discriminates the Bacteroidetes affiliated bacteria, as has been reported previously (Cottrell \& Kirchman 2000). In contrast, we had no indication of a biased amplification of phylotypes affiliated to Alphaproteobacteria by the Bacteriaspecific primer set. Of the 17 sequences of this subclass, 7 were amplified by the Bacteria-specific primer set and all except 1 sequence (GWS-e10-FL) were very closely related or similar to those amplified by the Alphaproteobacteria-targeted primer set (Fig. 4A). However, the latter and the Roseobacter-specific primer set yielded a much better resolution and detected substantially more phylotypes with a presumably lower abundance.

In contrast to PA phylotypes, the number of bands of Bacteroidetes in the FL bacterial fraction increased during the Guinardia delicatula bloom, suggesting that the DOC supply became more diverse, presumably including a variety of polymers released from growing and decaying diatoms and solubilizing phytodetrital aggregates. Two of the newly occurring phylotypes clustered together (GWS-c6-FL, GWS-c5-FL) and also together with other phylotypes which occurred on 14 June (GWS-e9-FL) in the FL bacterial fraction and in the PA bacterial fraction (GWS-c15-PA, Fig. 4B). These phylotypes are closely related to phylotypes which were retrieved from the associated bacterial communities of 2 diatoms (SB-42-DB, Schäfer et al. 2001; Flo-21, Grossart et al. 2005), suggesting that they are particularly adapted to the organic matter profile of diatoms.

Our results show that organisms of the Bacteroidetes and the Roseobacter-clade are most responsive to the changing organic matter field during the phytoplankton blooms and that DGGE patterns of the latter were significantly correlated to changes in the composition of the phytoplankton community. This is in line with other studies (Lebaron et al. 1999, Riemann et al. 2000, Fandino et al. 2001, Riemann \& Winding 2001, Dang \& Lovell 2002, Pinhassi et al. 2004, Grossart et al. 2005) and thus indicates that members of these 2 bacterial groups appear to be particularly adapted to such conditions, at least in temperate waters. There is evidence that marine bacteria affiliated with the classes Sphingobacteria and Flavobacteria of the Bacteroidetes phylum consume complex and polymeric DOC (Cottrell \& Kirchman 2000), obviously because of their specific properties to hydrolyze polymers (Kirchman 2002, Bauer et al. 2006). The significance of the Roseobacter-clade is much less well understood. Some members of this clade exhibit aerobic anoxygenic photosynthesis (Allgaier et al. 2003) but the significance of this metabolic pathway with ambient conditions and varying trophic state is still unclear (Schwalbach \& Fuhrman 2005). Other members of this clade are involved in the decomposition of DMS and were found as prominent members of the bacterioplankton community during DMS-producing phytoplankton blooms (González et al. 2000, Zubkov et al. 2001, Moran et al. 2003). Roseobacter phylotypes and strains have been detected and/or isolated from FL as well as PA bacterial communities closely associated with algae (Allgaier et al. 2003, Grossart et al. 2005), and quite a few of the isolates exhibit antibiotic and quorum-sensing properties (Long \& Azam 2001, Gram et al. 2002, Grossart et al. 2004, Martens et al. 2007). These specific properties related to distinct phytoplankton communities or even populations may explain the close correlation of the Roseobacter subcommunity to the phytoplankton composition in the Wadden Sea.

The combined application of Bacteria- and groupspecific primer sets revealed that a hierarchical struc- 
ture exists in the bacterial communities, both in the FL as well as the PA fractions. The Bacteria-specific primer set detected mainly those phylotypes that constitute the main and often dominant components of the bacterial communities, persisting almost permanently and thus comprising bacteria able to adapt to quite variable environmental conditions and exhibiting a rather generalistic life style. These phylotypes include members of the widely distributed RCA cluster (Selje et al. 2004) and of the WAC I cluster of the Roseobacter-clade, which appears to have a more restricted distribution to coastal regions (Stevens et al. 2005b). In contrast, the group- and clade-specific primer sets detect, besides some of these generalistic phylotypes, others that are probably less abundant but appear under distinct environmental and biotic conditions, such as during certain periods of phytoplankton blooms. The phylotypes detected by these primer sets reflect in a more sensitive way these changing conditions and thus allow a more detailed analysis of bacterial communities under varying environmental conditions. The application of Bacteria-specific primer sets appears to be appropriate for studying the main components of bacterial communities and their variability at greatly varying environmental conditions such as in salinity gradients (Troussellier et al. 2002, Selje \& Simon 2003), PA vs. FL bacterial communities (Stevens et al. 2005a), or in manipulated mesocosms (Lebaron et al. 1999, Riemann et al. 2000, Pinhassi et al. 2004). In other cases, when more subtle variations or discrimination against specific target groups may occur, this approach appears to be not sufficiently sensitive to comprehensively detect these changes. In such cases, the application of more specific primer sets is a valuable tool for detecting these changes, which are an important indication of distinct responses of the bacterial communities to their changing environment.

Acknowledgements. We appreciate the constructive suggestions of 3 reviewers that helped to improve the manuscript. The hospitality and assistance of the RV 'Senckenberg' crew is gratefully acknowledged. We thank B. Kuerzel and R. Weinert for dry weight analyses and H.P. Grossart for valuable discussions. This work was supported by the Deutsche Forschungsgemeinschaft (DFG) within the research group 'BioGeoChemistry of Tidal Flats' (FG 432 TP5).

\section{LITERATURE CITED}

Abell GCJ, Bowman JP (2005) Colonization and community dynamics of class Flavobacteria on diatom detritus in experimental mesocosms based on Southern Ocean seawater. FEMS Microbiol Ecol 53:379-391

Allgaier M, Uphoff H, Wagner-Döbler I (2003) Aerobic anoxygenic photosynthesis in Roseobacter-clade bacteria from diverse marine habitats. Appl Environ Microbiol 69: 5051-5059
Azam F, Fenchel T, Field JG, Gray JS, Meyer-Reil LA, Thingstad F (1983) The ecological role of water-column microbes in the sea. Mar Ecol Prog Ser 10:257-263

Bauer $M$, Kube $M$, Teeling $H$, Richter $M$ and 14 others (2006) Whole genome analysis of the marine Bacteroidetes Gramella forsetii reveals adaptations to degradation of polymeric organic matter. Environ Microbiol 8: 2201-2213

Brinkhoff T, Muyzer G (1997) Increased species diversity and extended habitat range of sulfur-oxidizing Thiomicrospira spp. Appl Environ Microbiol 63:3789-3796

Brinkhoff T, Bach G, Heidorn T, Liang L, Schlingloff A, Simon M (2004) Antibiotic production by a Roseobacter-cladeaffiliated species from the German Wadden Sea and its antagonistic effects on indigenous isolates. Appl Environ Microbiol 70:2560-2565

Brinkmeyer R, Rappé M, Gallacher S, Medlin L (2000) Development of clade- (Roseobacter and Alteromonas) and taxon- specific oligonucleotide probes to study interactions between toxic dinoflagellates and their associated bacteria. Eur J Phycol 35:315-329

Castle D, Kirchman DL (2004) Composition of estuarine bacterial communities assessed by denaturing gradient gel electrophoresis and fluorescence in situ hybridization. Limnol Oceanogr Methods 2:303-314

Cole JJ, Findlay S, Pace ML (1988) Bacterial production in fresh and saltwater ecosystems: a cross-system overview. Mar Ecol Prog Ser 43:1-10

Cottrell MT, Kirchman DL (2000) Natural assemblages of marine proteobacteria and members of the CytophagaFlavobacter cluster consuming low- and high-molecularweight dissolved organic matter. Appl Environ Microbiol 66:1692-1697

Crump BC, Baross JA, Simenstad CA (1998) Dominance of particle-attached bacteria in the Columbia River estuary, USA. Aquat Microb Ecol 14:7-18

Dang H, Lovell CR (2002) Seasonal dynamics of particle-associated and free-living marine Proteobacteria in a salt marsh tidal creek as determined using fluorescence in situ hybridization. Environ Microbiol 4:287-295

Fandino LB, Riemann L, Steward GF, Long RA, Azam F (2001) Variations in bacterial community structure during a dinoflagellate bloom analyzed by DGGE and 16S rDNA sequencing. Aquat Microb Ecol 23:119-130

Giuliano L, De Domenico M, De Domenico E, Höfle MG, Yakimov MM (1999) Identification of culturable oligotrophic bacteria within naturally occurring bacterioplankton communities of the Ligurian Sea by 16S rRNA sequencing and probing. Microb Ecol 37:77-85

González JM, Simo R, Massana R, Covert JS, Casamayor EO, Pedros-Alio C, Moran MA (2000) Bacterial community structure associated with a dimethylsulfoniopropionateproducing North Atlantic algal bloom. Appl Environ Microbiol 66:4237-4246

Gram L, Grossart HP, Schlingloff A, Kiorboe T (2002) Possible quorum sensing in marine snow bacteria: production of acylated homoserine lactones by Roseobacter strains isolated from marine snow. Appl Environ Microbiol 68: 4111-4116

Grossart HP (1999) Interactions between marine bacteria and axenic diatoms (Cylindrotheca fusiformis, Nitzschia laevis, and Thalassiosira weissflogii) incubated under various conditions in the lab. Aquat Microb Ecol 19:1-11

Grossart HP, Schlingloff A, Bernhard M, Simon M, Brinkhoff $T$ (2004) Antagonistic activity of bacteria isolated from organic aggregates of the German Wadden Sea. FEMS Microbiol Ecol 47:387-396 
Grossart HP, Levold F, Allgaier M, Simon M, Brinkhoff T (2005) Marine diatom species harbour distinct bacterial communities. Environ Microbiol 7:860-873

Jaspers E, Nauhaus K, Cypionka H, Overmann J (2001) Multitude and temporal variability of ecological niches as indicated by the diversity of cultivated bacterioplankton. FEMS Microbiol Ecol 36:153-164

Johnson W, Lewitus AJ, Fletcher M (2006) Linking bacterioplankton community structures to environmental state variables and phytoplankton assemblages in 2 South Carolina salt marsh estuaries. Aquat Microb Ecol 45:129-145

Kirchman DL (2002) The ecology of Cytophaga-Flavobacteria in aquatic environments. FEMS Microbiol Ecol 39: 91-100

Kirchman DL, Yu L, Cottrell MT (2003) Diversity and abundance of uncultured Cytophaga-like bacteria in the Delaware estuary. Appl Environ Microbiol 69:6587-6596

Larsen A, Flaten GAF, Sandaa RA, Castberg T, Thyrhaug R, Erga SR, Jacquet S, Bratbak G (2004) Spring phytoplankton bloom dynamics in Norwegian coastal waters: microbial community succession and diversity. Limnol Oceanogr 49:180-190

Lebaron P, Servais P, Troussellier M, Courties C and 6 others (1999) Changes in bacterial community structure in seawater mesocosms differing in their nutrient status. Aquat Microb Ecol 19:255-267

Long RA, Azam F (2001) Antagonistic interactions among marine pelagic bacteria. Appl Environ Microbiol 67: 4975-4983

Ludwig W, Strunk O, Westram R, Richter L and 28 others (2004) ARB: a software environment for sequence data. Nucleic Acids Res 32:1363-1371

Lunau M, Lemke A, Dellwig O, Simon M (2006) Physical and biogeochemical controls of microaggregate dynamics in a tidally affected coastal ecosystem. Limnol Oceanogr 51: 847-859

Manz W, Amann R, Ludwig W, Vancanneyt M, Schleifer KH (1996) Application of a suite of 16S rRNA-specific oligonucleotide probes designed to investigate bacteria of the phylum cytophaga-flavobacter-bacteroides in the natural environment. Microbiology 142:1097-1106

Martens T, Gram L, Grossart HP, Kessler D, Müller R, Simon M, Wenzel SC, Brinkhoff $T$ (2007) Bacteria of the Roseobacter-clade show potential for secondary metabolite production. Microb Ecol (in press)

Messing J (1983) New M13 vectors for cloning. Methods Enzymol 101:20-78

Moran MA, Gonzalez JM, Kiene RP (2003) Linking a bacterial taxon to sulfur cycling in the sea: studies of the marine Roseobacter group. Geomicrobiol J 20:375-388

Muyzer G, de Waal EC, Uitterlinden AG (1993) Profiling of complex microbial populations by denaturing gradient gel electrophoresis analysis of polymerase chain reactionamplified genes coding for 16S rRNA. Appl Environ Microbiol 59:695-700

Muyzer G, Brinkhoff T, Nübel U, Santegods C, Schäfer H, Wawer C (1998) Denaturing gradient gel electrophoresis (DGGE) in microbial ecology. Molecular microbial ecology manual. Kluwer Academic Publishers, Dordrecht, p 1-27

Neef A (1997) Anwendung der in-situ-Einzell-Identifizierung von Bakterien zur Populationsanalyse in komplexen mikrobiellen Biozönosen. PhD thesis, Technische Universität München
Pinhassi J, Sala MM, Havskum H, Peters F, Guadayol O, Malits A, Marrase CL (2004) Changes in bacterioplankton composition under different phytoplankton regimes. Appl Environ Microbiol 70:6753-6766

Riemann L, Winding A (2001) Community dynamics of free-living and particle-associated bacterial assemblages during a freshwater phytoplankton bloom. Microb Ecol 42:274-285

Riemann L, Steward GF, Azam F (2000) Dynamics of bacterial community composition and activity during a mesocosm diatom bloom. Appl Environ Microbiol 66:578-587

Sambrook J, Frisch EF, Maniatis T (1989) Northern hybridisation. In: Nolan C (ed) Molecular cloning: a laboratory manual, 2nd edn. Cold Spring Harbour Laboratory Press, New York 7.42

Schäfer H, Bernard L, Courties C, Lebaron P and 7 others (2001) Microbial community dynamics in Mediterranean nutrient-enriched seawater mesocosms: changes in the genetic diversity of bacterial populations. FEMS Microbiol Ecol 34:243-253

Schäfer H, Abbas B, Witte H, Muyzer G (2002) Genetic diversity of 'satellite' bacteria present in cultures of marine diatoms. FEMS Microbiol Ecol 42:25-35

Schwalbach MS, Fuhrman JA (2005) Wide-ranging abundances of aerobic anoxygenic phototrophic bacteria in the world ocean revealed by epifluorescence microscopy and quantitative PCR. Limnol Oceanogr 50:620-628

Selje N, Simon M (2003) Composition and dynamics of particle-associated and free-living bacterial communities in the Weser estuary, Germany. Aquat Microb Ecol 30:221-237

Selje N, Simon M, Brinkhoff T (2004) A newly discovered Roseobacter cluster in temperate and polar oceans. Nature 427:445-448

Selje N, Brinkhoff T, Simon M (2005) Detection of abundant bacteria in the Weser estuary using culture-dependent and culture-independent approaches. Aquat Microb Ecol 39:17-34

Simon M, Grossart HP, Schweitzer B, Ploug H (2002) Microbial ecology of organic aggregates in aquatic ecosystems. Aquat Microb Ecol 28:175-211

Stevens H, Brinkhoff T, Simon M (2005a) Composition of freeliving, aggregate-associated and sediment surface-associated bacterial communities in the German Wadden Sea. Aquat Microb Ecol 38:15-30

Stevens H, Stübner M, Simon M, Brinkhoff T (2005b) Phylogeny of Proteobacteria and Bacteroidetes from oxic habitats of a tidal flat ecosystem. FEMS Microbiol Ecol 54: 351-365

Thioulouse J, Chessel D, Dolédec S, Olivier JM (1997) ADE-4: a multivariate analysis and graphical display software. Stat Comput 7:75-83

Troussellier M, Schäfer H, Batailler N, Bernard L and 5 others (2002) Bacterial activity and genetic richness along an estuarine gradient (Rhone River plume, France). Aquat Microb Ecol 28:13-24

Yager PL, Connelly TL, Mortazavi B, Wommack KE, Bano N, Bauer JE, Opsahl S, Hollibaugh JT (2001) Dynamic bacterial and viral response to an algal bloom at subzero temperatures. Limnol Oceanogr 46:790-801

Zubkov MV, Fuchs BM, Archer SD, Kiene RP, Amann R, Burkill PH (2001) Linking the composition of bacterioplankton to rapid turnover of dissolved dimethylsulphoniopropionate in an algal bloom in the North Sea. Environ Microbiol $3: 304-311$ 